\title{
The Reflection for Multimedia Teaching
}

\author{
Yan Dong (Corresponding author) \\ Department of Chemistry, Dezhou University \\ Dezhou 253023, China \\ Tel: 86-534-898-5576 E-mail: sddzdy@163.com \\ Rongchun Li \\ Department of Chemistry, Dezhou University \\ Dezhou 253023, China \\ E-mail: lirc78@126.com
}

The research is financed by Shandong higher school teaching reform program, Grant No. 2009079

\begin{abstract}
Today, multimedia teaching has been extensive used in teaching. Multimedia teaching has the advantages that traditional teaching model can't compare with. But we should avoid the disadvantages as well. Based on analysis of the disadvantages of multimedia teaching, we made some suggestions on applying it in teaching in this paper.

Keywords: Multimedia, Teaching, Disadvantage

\section{Introduction}

Along with the progress of the society, the development of science and technology, computers have complied with the new times development and have been used in almost all fields. As a bran-new modern teaching means, the computer aided teaching has been becoming the best choice of classroom teaching for its scientific, advanced, vivid and visual features. However, with the popularization of multimedia education technology, there are some opinions about its disadvantages such as information overmuch, multimedia offside, courseware content and quality is not high, teaching method undeserved, classroom activity and the teacher's role weakening, difficult to achieve the desired teaching effect, and so on. These problems make the main role in learning of the students can not materialize and can not promote the learning positivity of them. The purpose of multimedia teaching can not reach. So, teachers should consider the problems about how to overcome the disadvantages of multimedia classroom teaching and build new-type teaching structure and teaching mode that can reflect the subject role of students (He, 1998; Xie, 2010).
\end{abstract}

\section{Advantages of multimedia teaching}

Taking the English teaching, for example, as society advances, science and technology develops and the Internet emerges, the traditional teaching of English has been greatly challenged by many new ways. Now we teachers are confronted with many issues, such as how to raise students' interest in English learning, how to increase the efficiency of teaching during class. Multimedia for teaching is undoubtedly a good answer to the above questions. In the multimedia teaching, with eyes looking, ears listening, mouth speaking, hands writing, brains keeping in mind, students will greatly improve their passion for learning, leading to higher class efficiency (Li, 2009).

\subsection{Multi-media teaching makes English class more vivid, interesting and lively}

Multi-media teaching makes English class more vivid, interesting and lively, which could therefore stimulate students' interest in learning, improve class efficiency and achieve a more satisfactory teaching results. With pictures, sounds and animations, multi-media teaching can provide a number of dynamic implicit information associated with linguistic factors, such as cultural background knowledge, exotic customs and so on. In traditional class, the student are asked to listen to class mainly in order to receive information in a rather passive position. Besides, the practice designed for them are always those mechanical and repeated ones. By abandoning the above traditional methods that are not conducive to cultivate students' learning interest, multimedia teaching, a lively means, could provide vivid and realistic presentation and considerably improve teaching effect. 


\subsection{Multimedia teaching could create a language lively and harmonious environment}

In the process of training students' listening, speaking, reading and writing abilities, multimedia teaching could create a language lively and harmonious environment, provide a good learning scenario, increase practice in four basic skills and mobilize students to participate in class activities. When taking part in these activities concentratedly, the students will have a deeper impression and remember knowledge well. If students could see, hear and express their own ideas in their words, the knowledge grasped in this process will be easier to maintain compared with traditional teaching effect.

\subsection{Multimedia teaching could create a practical English using environment}

Multimedia teaching could create a practical English using environment, in which students could enhance their ability to use English.

The ultimate goal of learning English for students is the future use of English language. After all, English as a language is a communicative tool. If the students only emphasize learning the language instead of using it, then the result will become the failure of English teaching. Multimedia could associate with language and images. Through multi-sensory stimulation in learning process, the students will have access to more information.

Of course, multimedia teaching is a new phenomenon. In specific operations there will inevitably emerge some tough problems. However, we absolutely couldn't deny the advantages of multimedia teaching for the sake of its problems that could be overcome. In addition, I believe its superiority would be proved by time and will win popularity among teachers and students.

\section{Disadvantages of multimedia teaching}

Multimedia teaching has the advantages that traditional teaching model can't compare with. But it has some disadvantages also. They are listed as follows.

\subsection{Informative but can not highlight the importance}

Compared with the traditional teaching mode, one of the advantages of multimedia teaching is informative. But in the practical teaching process, some teachers ignored the importance of classroom teaching during designing of the courseware which result in excessive informative but can not highlight the importance. For fearing awkward silence in the class, teachers usually prepare several pages of PPT. At the same time, teachers can download abundant of information relevant the text. The messages are often used on the courseware without a word to refine. The result was the information input far beyond current level of students, student anxiety, which contusing the students' study enthusiasm badly.

Moreover, some teachers ignored the importance of students understanding and can not control the rhythm of the lectures demonstration. The click demo was too fast to follow. For some students, even if they can keep up with the lectures, they can not understand and digest them also. Some teachers don't require students to take notes but let them copy the file directly after class. Teachers just click demo, but didn't leave time for learners processing information. The students' instantaneous memory can not timely translate into short-term and long-term memory result in a large amount of information and much of knowledge become superfluous information like passing clouds, fleeting.

\subsection{Lack of interactive exercises, input/output imbalance}

Some teachers have weak concept in teaching results in drab content of the courseware. Lacking of openness and interactive activities makes input and output imbalance. The details are displayed as follows: The teacher stands on the platform, holding the mouse, demonstrates the courseware one by one naturally. Teachers take "cramming education" mode basically in which "courseware cramming" has $80 \%$ at least. So, the teacher is still master in teaching and students are still passive recipients of the external stimulation, which is always in the passive position. The only difference is the teaching media changed, from "chalk + blackboard" changed into multimedia teaching without improvement essentially.

\subsection{Formalist answer limiting the students' thinking}

In the practical teaching process, students answer questions are often depend on teachers answer especially in explaining definition and principle subjects. It's difficult to breakthrough the original framework and the standard answer. It's difficult for the teachers to make various extensions. As time passes, in this law, students become external stimulation recipients actually and won't put forward their own ideas. At the same time, teachers present the knowledge only but have no chance to discuss on some problems and communicate and question with the students for understanding each other's ideas and making corresponding adjustment. In a certain extent, the inappropriate use of some multimedia courseware fosterages inertia and weakens subjective initiative of students. 


\subsection{Courseware quality is not high, lack of interesting}

Multimedia technology can provide teaching resources including text, graphics, animation, image, sound and video information, which can greatly improve the learning interest of the students and promote their understanding and memory of knowledge (Tan, 2000). However, in the actual teaching process, most of the courseware was just reprint of paper material and the information mainly in the text and static images form due to teachers lacking considerable computer technology. The advantages of multimedia courseware can not be exhibited adequately. It can not help for students' interest, understanding and memory.

\section{Advices for multimedia teaching}

Based on above mentioned shortages, teachers should consider the problems about how to using multimedia timely to create a pleasant, democratic and harmonious environment to provide students a thinking platform and cultivate students' innovation consciousness, actively participate in thinking and team spirit. In practical teaching process, teachers should improve in the following aspects:

\subsection{Controlling information, increasing understanding input}

Firstly, the teacher should pay attention to controlling the information quantity in making courseware. Based on insight and arousing the original knowledge and experience of the students, the teacher input knowledge should be slightly higher than the current level of students. Although this can make students anxiety, it can stimulate the learning motivation and make the most students successful. If the input information is too easy, it can not mobilize students' learning interest and enthusiasm. Too hard, it can discourage students' study enthusiasm. Secondly, the teacher must keep firmly in mind that the teaching goal is to improve students' understanding when present courseware in class. Therefore, the courseware must be an elaborate design. The appropriate speed makes the students have time to understand and think. It's desired that teachers demonstrate suitable content at the right time in a reasonable way. If teachers are not care of rhythm and measures, students are easily "learning without thought is useless". In order to highlight the importance in the class, teachers can adopt different colors to display or choose pointer option in interpretation. Teachers can also choose zoom function before class or even slacken their rhythm to remind the students of the teaching emphasis and difficulty, strengthen their recognition and improve their understanding and memory.

\subsection{Designing more open practice, promoting students' positive thinking}

In order to exert the principal role of the students and make the meaning construction more effective in the teaching process, teachers should do as follows: First, put the appropriate questions for thinking and discussing. Second, try to deepen the questions step by step during discussion to enhance students understanding of the content. Third, inspire students to discover the rule by themselves (Yu \& Zhang, 2001).

\subsection{Improving courseware quality, arousing students' learning interest}

Briefly, multimedia consists of text, graphics, image, animation, sound and video et al. So teachers should choose suitable media to present different information and avoid by pure text means when designing the courseware. In information presentation way, teachers should choose to play according to paragraph and the content should not too much once appear. In addition, teachers should control the frequency of using images and text. Otherwise, not only the multimedia can not help in learning, but also it will make them the interference factors.

In summary, the application of multimedia in the teaching practice input the fresh blood for teaching job, greatly improved the efficiency of the classroom teaching and paved the way for education innovation. But it is only a kind of auxiliary teaching method. It can help students understand and master the teaching content better, but it can not replace the teaching content. Method can not replace purpose. The key is teachers whether the methods used appropriately. Only combining multimedia and teaching scientific and organically, we can exert the maximum efficiency and avoid or eliminate its negative effects of multimedia.

\section{References}

He, K. K. (1998). The development trends of the application of multimedia education. Chinese Medical Education Technology, 3, 130-132.

Li, X. (2009). The advantages and disadvantages of multimedia teaching. Chinese Journal of Electric Power Technique, 4, 43-44.

Tan, H. Q. (2000). Basis of multimedia application. Beijing: Tsinghua University Press.

Xie, M. F. (2010). "The Profit" and "Fraud" in Multimedia Teaching. Friends of Science Amateurs, 6, 156.

Yu, S. Q., \& Zhang, J. W. (2001). Introduction of education technology theory-teaching and practice of information age. Beijing: Higher Education Press. 